\title{
Gulf Region Students’ Acculturation into the Academic World: Qualitative Analysis of Data Process
}

\author{
Ghadah Al Murshidi ${ }^{1, *}$ \\ ${ }^{1}$ Department of Curriculum and Instruction, College of Education, UAE University, UAE \\ *Correspondence: Department of Curriculum and Instruction, College of Education, UAE University, UAE. E-mail: \\ g_almurshidi@uaeu.ac.ae
}

Received: April 16, 2014

Accepted: May 7, 2014 Online Published: May 15, 2014

doi:10.5430/wjel.v4n2p14

URL: http://dx.doi.org/10.5430/wjel.v4n2p14

\begin{abstract}
The study is a description of the analysis process of an ethnographic case study conducted on Academic Socialization of Gulf Region Students in U.S. Universities. The researcher reanalyzed the data using the qualitative analysis process. In the analysis, the unit of analysis that the researcher focused on is a group of Gulf Region students who are from the UAE and Saudi Arabia and currently studying at U.S. universities. The purpose of the research is describing the academic and social process of Gulf States undergraduate student's experiences. The academic Discourse references that informed by the literature are language socialization (Duff, 2007; 2010), academic discourse socialization (White \& Lowenthal, 2011), communities of practice (Lave \& Wenger, 1991), and literacy as social practice (Heath, 1983; Barton \& Hamilton, 1998; Street, 1995).
\end{abstract}

Keywords: thematic analysis; qualitative approach; academic discourse socialization; communities of practice; literacy as social practice

\section{Introduction}

This paper is a description of the analysis process of an ethnographic case study conducted on Academic Socialization of Gulf Region Students in U.S. Universities. Academic socialization is a process that students from one cultural and linguistic context undergo to acquire academic competencies in another context and become legitimate participants in their academic disciplines. The research interest is determined by the journey and struggles to acquire academic competencies to become a legitimate participant in an academic discipline are complex and long term. The initial struggles began with the participants from their decisions to study English in their native countries. Some of these struggles are linguistics, others are socio-cultural. Evidently, as Gulf region students, their primary language is Arabic, and English is their second language. Although their studies of the English language began at an early age, several issues in future years would impact the way the students speak, write, and communicate in "academic speak." This process was primarily influenced by their teachers and mentors, who relied mostly on grammar translation as opposed to communicative language teaching, speaking and listening. Collectively, these processes, totally unknown to them, accounted for the ways in which, in later years, the students would communicate in an academic discipline in a U.S. university context.

This situation, though not necessarily accurately perceived at the time, equally accounted for the many challenges the Gulf region students encountered during their first year at a US university setting. Even though they spoke English reasonably well, these communicative challenges provoked an internal struggle between their self-esteem and the quest to remedy the situation, and often not finding a method of oral or written expression that was acceptable to their peers and teachers. Because of these dilemmas and contradictions, the researcher has determined to do something about it: to investigate the little known complexity of this phenomenon, particularly in the Gulf region.

Acculturating into the academic world at the doctoral student level becomes more complex when it involves students whose home language and culture are different than that of the mainstream within the university. Such a situation makes their first year to be the most challenging and stressful year (Golde, 2000).

Having reflected on the Gulf region students' struggles as graduate students, the researcher tried to understand the 
experiences of others who go through academic socialization in U.S. universities and use newly gained knowledge to support undergraduate students from Gulf Regions and other areas of the world. The overarching question is: How "newcomers" from Gulf States socialize into their discourse communities or disciplines in the context of higher education?

The researcher reanalyzed the data using the qualitative analysis process. In the analysis, the unit of analysis that the researcher focused on is a group of Gulf Region students who are from the United Arab Emirates (UAE) and Saudi Arabia and currently studying at U.S. universities. The unit of observation is one UAE undergraduate student who is currently enrolled in a U.S. University. The purpose of the research is describing the academic and social process of Gulf States undergraduate student's experiences. The academic Discourse references informed by the literature are language socialization (Duff, 2007; 2010), academic discourse socialization (White \& Lowenthal, 2011), communities of practice (Lave \& Wenger, 1991), and literacy as social practice (Heath, 1983; Barton \& Hamilton, 1998; Street, 1995).

\section{Phase 1: Become Familiar with the Data}

In this phase, the researcher tried to follow the procedures Seidel, (1998), Aronson (1994) and Braun \& Clarke, (2006) recommended familiarizing the researcher's self with the data by reading and re-reading the data. The researcher tried to know "all aspects of the data", notice things, collect ideas, think about them and take notes during this process. The researcher immersed the researcher's self in the data and the research notes, the researcher engaged deeply in the words, impressions, and flow of events. The intention is becoming familiar with the depth and breadth of the content. Reading through the data many times assisted the researcher in extracting the inherent meanings. This helped the researcher to become more familiar with the data, generating an initial list of ideas about what is in the data and what is interesting about them, and helped me generate codes, the next phase of the analysis.

\section{Phase 2: Generating Initial Codes}

The researcher looked over their data to find patterns within the data that could be positioned into categories, which were used to code the data. A code is something that stands for a piece of information that depicts what each piece is about, and a category stand for a class of objects. The researcher worked systematically through the entire data set, giving full and equal attention to each data item, identifying interesting aspects in the data items and collating data relevant to each code. The researcher followed Braun and Clarke' (2006) advice in this phase, which is: (a) code for as many potential themes/patterns as possible; (b) code extracts of data inclusively; (c) remember that you can code individual extracts of data in as many different 'themes' as they fit into. The researcher retained accounts that departed from the dominant story in the analysis understanding that they might be of interest later. The following categories were identified: communication, academic progress. Once the categories were identified, the data were coded and placed in "boxes" to help see the patterns in the data as well as the contradictions. (See Table 1 for an example of codes applied to short segments of data.)

Table 1. Data Extract, With Codes Applied

\begin{tabular}{ll}
\hline Data extract & Coded for \\
\hline This semester I worked with two Americans and one from my friends & communication \\
the American students who are with us ... One was graduating so, he did not care & \\
about the grade. He can get A, B or C or F. He did not care. He wanted just to & \\
graduate and the other student did not work. & \\
$\underline{\text { I and my Emirati friend were working but at the end we got not a good grade. }}$ & \\
$\underline{\text { I prefer to work with Americans }}$ & \\
\hline $\begin{array}{l}\text { I and my friend, we are not good at writing because writing always is an obstacle } \\
\text { for me }\end{array}$ & academic progress \\
the American students who are with us. One was graduating so, he did not care & \\
$\underline{\text { about the grade. He can get A, B or C or F. He did not care. He wanted just to }}$ & \\
graduate & \\
I and my Emirati friend were working but at the end we got not a good grade. & \\
\hline
\end{tabular}




\section{Phase 3: Searching, Reviewing, Refining Themes}

This phase of the analysis re-focused the analysis at the broader level of themes. Through the pulling apart of data into categories and analyzing its content themes began to emerge (Stake, 1995). The researcher began analyzing the codes and understanding how various codes may combine to form an overarching theme (Braun \& Clarke, 2006). The researcher sorted the different codes into potential themes and collated all the related coded data extracts within the indicated themes. The researcher continued noticing things, collecting things (ideas), thinking about the relationship between the codes, between themes and between various levels of themes. Checking if the themes worked in relation to the coded extracts, the researcher read all the collated extracts for each theme, and considered whether they appeared to form a coherent pattern. The researcher ended this phase with a collection of candidate themes and sub-themes, and all extracts of data that had been coded in relation to them. The researcher had a quite clear image of the themes, how they fit together, and the overall story they tell about the data. See figure 1 for an example of a candidate theme.

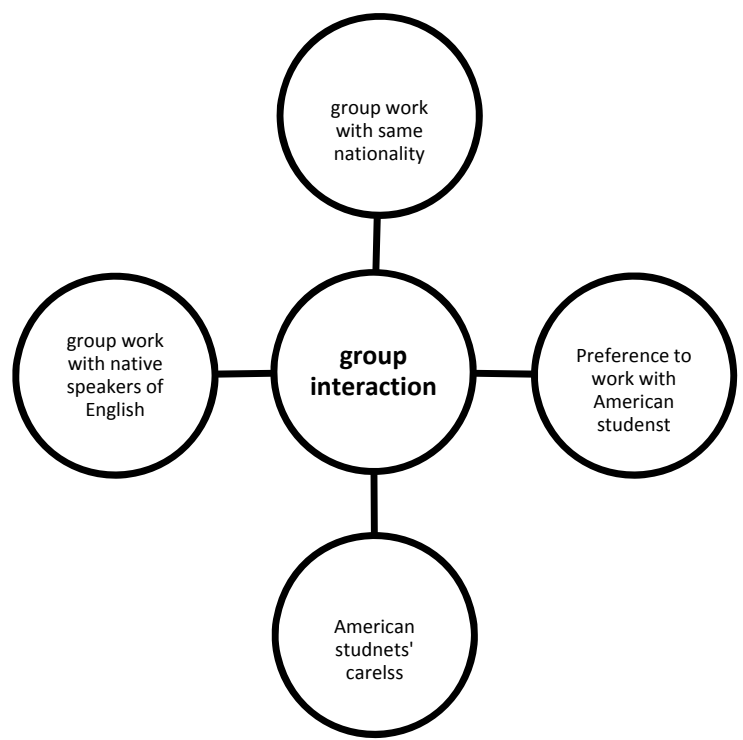

Figure 1. Initial Thematic Map, Showing One of the Candidate Themes

\section{Phase 4: Refining, Defining \& Naming Themes}

At the refining, defining and naming the themes phase of the analysis, the researcher defined and further refined the themes the researcher would present for the analysis. 'Define and refine' means indicating the 'essence' of what each theme is about and determining what aspect of the data each theme captures. For each theme the researcher did and wrote a detailed analysis, and the researcher identified the story that each theme informs. Some general themes are noticeable from the pulling apart and putting back together of the data. In finding the core themes the researcher gave "priority to topics on which substantial amount of data has been collected and which reflected recurrent or underlying patterns of activities in the setting under study" (Emerson, 1995, p. 157). The themes that the researcher created from the data analyzed are: the various cultural communication skills, the misconception of learning, the conceptualization of Academic accomplishment. Within the themes are sub-themes that help shape the themes through thick description (see figure 2). These eventual final themes and sub-themes resulted from a process of refinement of initial themes and sub-themes. For instance, one of the themes that the researcher recognized is the various cultural communication skills. The researcher looked at all collated extracts that related to this theme, combined and catalogued related collated extracts into subthemes, thus I have the subthemes of: lack of group interaction, sufficient group interaction and communication proficiency, etc. The researcher also combined and catalogued related collated extracts for the subthemes. For instance, for the subtheme of the various cultural communication skills, some of the collated extracts consist of: This semester I worked with two Americans and one from my friends, the American students who are with us ... One was graduating so, he did not care about the grade. He can get A, B or C or F. He did not care. He wanted just to graduate and the other student did not work., I and my Emirati friend were working but at the end we got not a good grade, etc. All qualitative research is phenomenological in nature, the theme, the various cultural communication skills, expressed the lived experience of gulf region undergraduate students in socializing in the academia in the U.S. universities, and the subthemes provide thick description of the communication process (See Figure 5, in the appendix 
that shows the grounded Theory model). This section of the analysis reveals some hypotheses which are language proficiency contributes to barriers for the UAE undergraduate student in socialization and academic attainment, and cultural background predisposes the UAE undergraduate student' academic expectations for themselves and others based on the grades.

The thematic analysis was strengthened by triangulation, particularly the use of a second analytic method to confirm findings. Cortazzi (2001) said that narrative "can inform reflexive analysis of various stages of doing ethnography." The researcher investigated the individuals' stories of Gulf region students who experiences some challenges in their study in U.S. universities (stories provided to the statement: tell me your academic experiences in your study in U.S. universities) and found specific sequences of action were repeated across diverse situations. Labov's model, then, assisted me to identify narrative components common across the accounts. For instance, students typically began their stories with an abstract or point of the story or summary of what was to follow, such as, "The first time we start the undergraduate program, there is a class called English 15.”Then, they provided a brief orientation to the narrative, the students who register for that class "This class, American takes it. The international students have another option.", and finally concluding with the students' replacements and progress to get to the followed level of Intensive English Communication program courses. In Figure 4, I presented the prototypic story that the student narrated concerning a writing class (English 15). This illustrates how a structural analysis of narrative can reinforce a thematic analysis and triangulation

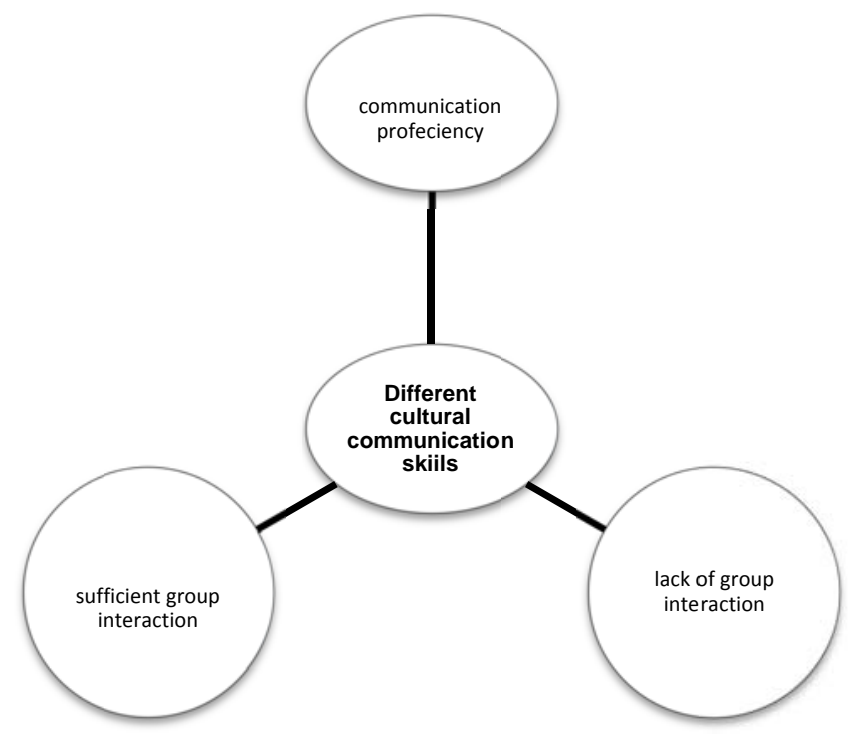

Figure 2. Final Thematic Map, Showing Final One of the Main Themes

Table 2. The Core Narrative: "Lap Top Lover/Use

\begin{tabular}{|c|c|c|}
\hline $\begin{array}{l}\text { Narrative } \\
\text { Elements }\end{array}$ & Definitions & Examples From Interviews \\
\hline Abstract (AB) & Summarize and/or "point" of the story & $\begin{array}{l}\text { The first time, we start the undergraduate } \\
\text { program. There is a class called English } 15 .\end{array}$ \\
\hline Orientation (OR) & Provides time, place, participants & $\begin{array}{l}\text { This class, American take it. The } \\
\text { international students have another option. }\end{array}$ \\
\hline Complicating Action (CA) & $\begin{array}{l}\text { Describes the event sequence, or plot, } \\
\text { usually with a turning point }\end{array}$ & $\begin{array}{l}\text { They can choose between English } 15 \text { as } \\
\text { American students or ESL 15. I took ESL } \\
15 \text {. }\end{array}$ \\
\hline Evaluation (EV) & $\begin{array}{l}\text { Where the narrator steps back from the } \\
\text { action to comment on meaning and } \\
\text { communicate emotions }\end{array}$ & $\begin{array}{l}\text { In the ESL } 15 \text {, they reinforce our basic } \\
\text { levels because they know that our English } \\
\text { language not as much }\end{array}$ \\
\hline ion (RE) & Outcome of the plot & \\
\hline Coda & $\begin{array}{l}\text { Ends the narrative and brings listener back } \\
\text { to the present }\end{array}$ & $\begin{array}{l}\text { and then they move us to the second level } \\
\text { and then finally the third level }\end{array}$ \\
\hline
\end{tabular}


Table 3. The Grounded Theory Model

\begin{tabular}{|c|c|c|c|c|}
\hline Data extract & Initial coding & $\begin{array}{l}\text { Focused } \\
\text { coding }\end{array}$ & $\begin{array}{l}\text { Beginnings of } \\
\text { Conceptual } \\
\text { Categories }\end{array}$ & $\begin{array}{l}\text { Conceptual } \\
\text { Categories }\end{array}$ \\
\hline & Open & Axial I & Axial II & \\
\hline $\begin{array}{l}\text { This semester I worked with two } \\
\text { Americans and one from my friends }\end{array}$ & $\begin{array}{l}\text { Group work with } \\
\text { different ethnic } \\
\text { groups }\end{array}$ & $\begin{array}{l}\text { Communication } \\
\text { proficiency }\end{array}$ & & communication \\
\hline $\begin{array}{l}\text { the American students who are with } \\
\text { us ... One was graduating so, he did not } \\
\text { care about the grade. He can get A, B or } \\
\text { C or F. He did not care. He wanted just to } \\
\text { graduate and the other student did not } \\
\text { work. }\end{array}$ & $\begin{array}{l}\text { Apathy in } \\
\text { American } \\
\text { students }\end{array}$ & $\begin{array}{l}\text { Lack of group } \\
\text { interaction }\end{array}$ & $\begin{array}{l}\text { different } \\
\text { cultural } \\
\text { communication } \\
\text { skills }\end{array}$ & \\
\hline $\begin{array}{l}\text { I and my Emirati friend were working } \\
\text { but at the end we got not a good grade. }\end{array}$ & $\begin{array}{l}\text { Effective work } \\
\text { and } \\
\text { communication } \\
\text { with the same } \\
\text { ethnic group and } \\
\text { same native } \\
\text { language speakers }\end{array}$ & $\begin{array}{l}\text { Sufficient } \\
\text { group } \\
\text { interaction }\end{array}$ & & \\
\hline$\underline{\text { I prefer to work with Americans }}$ & $\begin{array}{l}\text { Preferences for } \\
\text { working with } \\
\text { Americans } \\
\text { (native speakers } \\
\text { of English) }\end{array}$ & $\begin{array}{l}\text { Perception of } \\
\text { group work } \\
\text { with native } \\
\text { speakers of } \\
\text { English }\end{array}$ & the & samis \\
\hline $\begin{array}{l}\text { I and my friend, we are not good at } \\
\text { writing because writing always is an } \\
\text { obstacle for me }\end{array}$ & $\begin{array}{l}\text { Challenge to } \\
\text { write/compos } \\
\text { English }\end{array}$ & $\begin{array}{l}\text { Perception } \\
\text { /identity/ } \\
\text { characteristics }\end{array}$ & $\begin{array}{l}\text { the } \\
\text { misconception } \\
\text { of learning }\end{array}$ & $\begin{array}{l}\text { academic } \\
\text { progress }\end{array}$ \\
\hline $\begin{array}{l}\text { the American students who are with } \\
\text { us.One was graduating so, he did not } \\
\text { care about the grade. He can get A, B } \\
\text { or C or F. He did not care. He wanted } \\
\text { just to graduate }\end{array}$ & $\begin{array}{l}\text { Insignificance of } \\
\text { Grades for } \\
\text { American } \\
\text { graduate student }\end{array}$ & $\begin{array}{l}\text { The } \\
\text { relationship } \\
\text { between the } \\
\text { grades and the } \\
\text { academic }\end{array}$ & $\begin{array}{l}\text { The } \\
\text { conceptualization } \\
\text { of Academic } \\
\text { accomplishment }\end{array}$ & \\
\hline $\begin{array}{l}\text { I and my Emirati friend were working } \\
\text { but at the end we got not a good grade. }\end{array}$ & $\begin{array}{l}\text { Disappointment } \\
\text { of bad grades } \\
\text { even the hard } \\
\text { work }\end{array}$ & success & & \\
\hline $\begin{array}{l}\text { 1. Language proficiency contributes to bar } \\
\text { attainment } 2 \text {.Cultural background predisp } \\
\text { and others based on the grades. }\end{array}$ & $\begin{array}{l}\text { hypothese } \\
\text { ers for the UAE un } \\
\text { es the UAE underg }\end{array}$ & $\begin{array}{l}\text { lergraduate stud } \\
\text { aduate student' }\end{array}$ & $\begin{array}{l}\text { in socialization } \\
\text { demic expectati }\end{array}$ & $\begin{array}{l}\text { ad academic } \\
\text { is for themselves }\end{array}$ \\
\hline
\end{tabular}




\section{Phase 5: Producing the Report}

During this stage, the final analysis and write-up of the report is conducted. "The task of the write-up of a thematic analysis ... is to tell the complicated story of your data in a way which convinces the reader of the merit and validity of your analysis" (Braun \& Clarke, 2006. p. 93). The report provided vivid compelling extract examples "which capture the essence of the point [I was] demonstrating” (p.93). The researcher tried to provide a clear, concise, coherent, logical, non-repetitive and interesting account of the story the data informs, within and across themes. Here is an excerpt from the analytic research report:

The academic socialization is a process that the UAE student whose language is Arabic and culture is Middle East undergo to acquire academic competencies in U.S. University and become legitimate participant in his academic discipline. The data has revealed through interview that the UAE student's communication experience with American students in their group work is critical because of the different cultures. Generally, he prefers to work with American students because they are native speakers of English to get better written product and higher grade. However, his exceptional experience with an American graduating student expressed the American student's apathy about grades and academic success. His sufficient workgroup interaction was with a student who shares his native language and culture. In an interview with the UAE student, he states,

"I prefer to work with American. This semester I worked with two American and one form from my friends. I and my other friend, we are not good at writing because writing is always an challenge for me. Therefore, the American students who are with us. One was graduating so, he did not care about the grade. He can get $A, B$ or $C$ or F. He did not care. He wanted just to graduate, and the other student did not work. This situation was rare in the Americans. I and my Emirati friend were working but at the end we got not a good grade."

\section{Conclusion}

Although the researcher did not realize it at the time, the questions formulated by the researcher's initial experience gave rise to the researcher's substantive interest which, in turn, gave rise to the researcher's epistemic interest. The epistemic interest of study was to describe the academic and social process of Gulf States undergraduate student's experiences. Therefore, I used thematic analysis informed by Van Manen (1997), Moustakas (1994). The thematic analysis was also informed by Boyatzis (1998) and Braun \& Clarke (2006) because the researcher followed the phases suggested by them in order to familiarize the researcher's self with the data.

Through this experience, the researcher recognizes that the epistemic interest of the study does drive the thematic analysis used. The study was an ethnographic case study; therefore the researcher used thematic analysis. Ethnography and phenomenological case study would use this process in addition to other processes in order to address their epistemic interests. The researcher perceives two different potential pitfalls to the process of thematic analysis: a weak or unconvincing analysis where the themes do not appear to work, and because the researcher had come into this experience with the researcher's preconceived notions of academic socialization process of Gulf region students, failing to move from a theory driven analysis to a data driven analysis whenever essential was challenging. The researcher realized that reflecting on the data and ensuring that its iterative nature is preserved are other good strategies to avoid these pitfalls.

\section{References}

Aronson, J. (1994). A pragmatic view of thematic analysis. The Qualitative Report, 2(1). Retrieved June 25, 2011 from http://www.nova.edu/ssss/QR/BackIssues/QR2-1/aronson.html

Boyatzis, R. E. (1998). Structure of a useful, meaningful code. In Transforming qualitative information: thematic analysis and code development (p. 31-33). Thousand Oaks, CA: Sage Publications.

Braun, V., \& Clarke, V. (2006). Using thematic analysis in psychology. Qualitative Research in Psychology, 3(2), 77-101. http://dx.doi.org/10.1191/1478088706qp063oa

Cortazzi, M. (2001). Narrative analysis in ethnography. In P. Atkinson, A. Coffey, S. Delamont, J Lofland, \& L. Lofland, Handbook of ethnography (pp. 384-394). London, SAGE Publications. http://dx.doi.org/10.4135/9781848608337.n26

Creswell, W. J. (2007). Qualitative inquiry and research design: Choosing among five approaches ( ${ }^{\text {nd }}$ ed.). Thousand Oaks, CA: Sage. 
Emerson, R.M., Fretz, R.I., \& Shaw, L.L. (1995). Writing ethnographic fieldnotes. Chicago: The University of Chicago Press. http://dx.doi.org/10.7208/chicago/9780226206851.001.0001

Golde, C. (2000). Should I stay of should I go? Student description of the doctoral attrition process. Review of Higher Education, 23(2), 119-227.

Labov, W. (2001). Uncovering the event structure of narrative. Georgetown University Round Table, 1-23. Retrieved July 2, 2011 from http://www.ling.upenn.edu/ wlabov/uesn.pdf

Moustakas, R. (1994). Phenomenological research: Analyses \& examples. In Phenomenological research methods (pp. 103-154). Thousand Oaks, CA: Sage.

Reissman, C. (2007). Narrative Methods for the Human Sciences. Thousand Oaks, CA: Sage Publications.

Rossman, G. B., \& Rallis, S. F. (2003). Learning in the field: An introduction to qualitative research ( $2^{\text {nd }}$ ed.). Thousand Oaks, CA: Sage.

Seidel, J. V. (1998). Qualitative Data Analysis. Qualis Research. Retrieved January 29, 2014 from ftp://ftp.qualisresearch.com/pub/qda.pdf

Stake, R.E. (1995). The art of case study research. Thousand Oaks: Sage Publications.

Van Manen, Max. (1997). Hermeneutic phenomenological reflections. In Researching lived experience: Human science for an action sensitive pedagogy ( $2^{\text {nd }}$ edition) (77-109). Albany: SUNY. 